\title{
Aplikasi Pintar : Hukum Tajwid Berbasis Android
}

\author{
Silvia Ayunda Murad ${ }^{1)}$, Dadang Sujana ${ }^{2 *}$, Ahmad Muhtiyar ${ }^{3 *}$ \\ *Jurusan Teknik Informatika, Fakultas Teknik, Universitas Islam Syekh Yusuf, Jl. Mulana Yusuf No.10 Tangerang \\ Banten 15118, Indonesia (10pt normal italic) \\ 1) silvia.ayunda@unis.ac.id \\ 2) dadangsujana@unis.ac.id \\ 3) Tiyarmuh10@gmail.com
}

\begin{abstract}
Abstrak. Teknologi informasi sekarang ini sudah semakin berkembang, kebutuhan akan sebuah informasi yang berkualitas sangatlah diperlukan. Perkembangan teknologi banyak mempengaruhi tatanan hidup atau sebuah aturan dan sistem tertentu yang dapat di manfaatkan dalam berbagai bidang, salah satunya yaitu dalam bidang pendidikan. Sistem yang di rangkum menjadi sebuah konsep e-Learning ini membawa pengaruh terjadinya proses transformasi pendidikan ke dalam bentuk digital baik secara content maupun sistem. Universitas Islam Syekh Yusuf atau dikenal dengan UNIS Tangerang memiliki salah satu fakultas yang bernama Ilmu Agama. Salah satu matakuliah pentingnya adalah pemahaman terhadap penggunaan tajwid didalam Al-Quran. Dengan menggunakan metode aplikatif penelitian ini dibangun dengan tujuan memudahkan para mahahasiswa dalam memahami setiap ilmu tajwid yang dipelajarinya karena dijelaskan satu persatu dari ilmu tajwid tersebut, dan juga metode ini mempermudah dosen dalam melakukan transfer knowledge kepada mahasiswa. Dengan model pembelajaran yang interaktif terbukti hasilnya lebih maksimal diukur dari nilai kelulusan mahasiswa di matakuliah ini yang mengalami kenaikan mencapai $70 \%$.
\end{abstract}

Kata kunci: e-learning, ilmu tajwid, android, smartphone

\begin{abstract}
Smart Application: Android Based Tajweed Rules]. Information technology is now growing, the need for quality information is needed. The development of technology has a lot to influence the order of life or a certain rule and system that can be utilized in various fields, one of which is in the field of education. The system, which is summarized into an e-Learning concept, has an effect on the transformation of education into digital form both in content and systems. UNIS Tangerang has a faculty called the Science of Religion. One of the important subjects is understanding the use of recitation in the Koran. By using an applicative method, this research was built with the aim of making it easier for students to understand each tajwid science they learn because it explains one by one from the knowledge of tajwid, and also this method makes it easier for lecturers to transfer knowledge to students. With an interactive learning model, it is proven that the results are maximally measured by the passing scores of students in this course up to $70 \%$.
\end{abstract}

Keywords: author guidelines, Technique Journal, article template

\section{Pendahuluan}

Seperti yang terlihat dalam beberapa tahun terakhir, dapat dengan cepat dipahami bahwa Internet mengubah cara kita bekerja dan bahkan cara kita belajar. Terlebih di kondisi dunia saat ini, kita dapat menyaksikan semakin tingginya minat di terkait elearning, tidak hanya dari organisasi komersial, tetapi juga dari lembaga akademik. Pada tingkat global, dapat diamati dengan baik bahwa pasar untuk produk dan layanan pendidikan berkembang dengan sangat pesat.
Di Indonesia, pembelajaran daring di pendidikan tinggi merupakan salah satu program Pemerintah Republik Indonesia sebagai solusi untuk meningkatkan akses mahasiswa terhadap mata kuliah bermutu, dari pendidikan tinggi atau para dosen yang bermutu. Melalui Kemenristekdikti, Pemerintah Republik Indonesia telah melakukan inisiatif dengan menyediakan fasilitas pembelajaran daring (lihat gambar 1) yang diresmikan tanggal 15 Oktober 2014 oleh Wakil Presiden. 


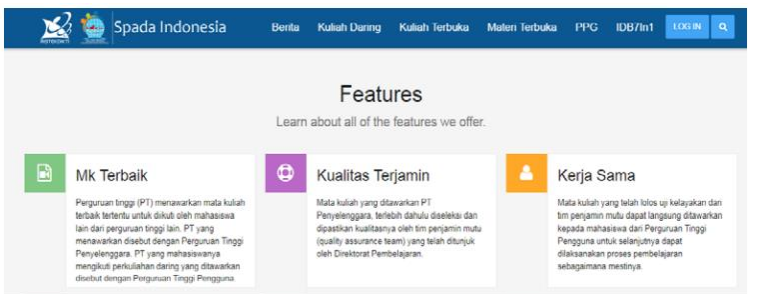

Gambar 1. Sistem Pembelajaran Daring Indonesia (SPADA Indonesia)

(Sumber : https://spada.ristekdikti.go.id/)

Pembelajaran daring tersebut di Indonesia lebih dikenal dengan e-learning.

E-learning menjadi semakin penting karena berbagai alasan, seperti munculnya informasi dan global ekonomi dan munculnya budaya konsumen. Mahasiswa abad ke-21 menuntut struktur yang fleksibel dan memungkinkan mereka untuk belajar, bekerja dan berperan serta dalam kehidupan keluarga pada waktu yang sama. Fleksibilitas ini tercermin dalam alternatif metode pengiriman yang mencakup penggunaan Internet. Orang-orang juga menjadi lebih peka terhadap budaya dan gender perbedaan, dan untuk kebutuhan belajar yang lebih menantang, kebutuhan yang mungkin saja terselesaikan dan terbantu dengan adanya e-learning.

Berbagai kalangan menyatakan bahwa Pendidikan merupakan asset utama didalam pengembangan sumber daya manusia di berbagaia level kepentingan perusahaan (Walter W. McMahon dan Terry G. Geske, 1982). Pendidikan tidak hanya sebagai formalitas skill yang dimiliki pekerja namun juga kebutuhan terkait level, kenaikan jenjang dan benefitbenefit lain yang ditawarkan perusahaan pada saat merekrut seorang calon karyawan. Dan ini tentu saja membutuhkan kemampuan terbaik yang dimiliki oleh seorang calon pekerja yang mulai dipersiapkan institusi pendidikannya pada saat dia berproses didalam penyelesaian study nya.

Seiring TI menjadi lebih kuat dan lebih mudah digunakan, maka pemanfaatannya sampai ke aktivitas akademik di pendidikan tinggi. Sistem manajemen Pendidikan tinggi memungkinkan pengajar dengan mudah mengintegrasikan teknologi kedalam pengajaran mereka. Komunikasi online dan akses informasi memperluas jangkauan pembelajaran hingga ke mana pun dan kapan pun seorang pengajar atau pelajar untu belajar Tirziu, A. M., \& Vrabie, C. (2015). Semakin tinggi bandwidth jaringan yang menyediakan saluran yang cepat dan efisien untuk menyelesaikan aktivitas ini maka semakin baik hasilnya (Andersson dan Grönlund, 2009).

Karena semakin banyak institusi yang mengadopsi strategi e-learning, keberhasilan mereka tidak hanya bergantung pada ketersediaan teknologi tetapi juga sejauh mana fakultas dan mahasiswa didukung saat mereka mengeksplorasi dan mengembangkan cara-cara inovatif untuk mengintegrasikan teknologi ke dalam pengalaman belajar. Praktik pedagogis harus disesuaikan, kecakapan teknis menjadi lebih penting, dan infrastruktur teknis yang andal dan kuat harus dimiliki dipertahankan untuk menggunakan e-learning secara efektif . Tuntutan ini diterjemahkan menjadi sejumlah profesor baru dan persyaratan dukungan siswa yang harus ditangani oleh institusi (Wright, 2010).

Penggunaan teknologi dalam pendidikan, umumnya didefinisikan sebagai e-learning, telah menjadi komponen standar dalam banyak hal kursus. Aplikasi teknologi tidak terbatas pada ruang kelas mereka juga menempatkan beberapa sesi kelas dengan sesi virtual atau sepenuhnya mengganti kursus kelas dengan kursus online.

Proses pembelajaran yang diukur dari proses traansformasi pembelajaran tentu saja sangat terbantu dengan memaksimalkan fungsi teknologi. Tertutama di kondisi saat ini. Anak-anak jaman milenial memiliki ke ciriannya sendiri dalam menerima pembelajaran. Salah satunya adalah pemanfaatn teknologi android sebagai pendukung aplikasi berbasis mobile.

Penelitian ini menjadi dasar pemikiran bagaimana pemanfaatan teknologi informasi didalam proses belajar mahasiswa dapat meningkatkan prestasi akademik serta minat belajar mahasiswa. Apabila terbukti, maka penelitian akan dilanjutkan untuk membuat model pembelajaran yang tepat bagi para Dosen pengajar di lingkungan UNIS Tangerang serta teknologi informasi yang paling tepat digunakan sebagai media pembelajaran dan dapat diterima secara utuh, digunakan serta dimanfaatkan oleh para Dosen sehingga baik mahasiswa maupun Dosen nyaman didalam menggunakannya (Murad, D. F., et. al, 2020).

Mengadobsi beberapa referensi yang kami gunakan, diketahui bahwa hasil Penelitian tersebut terbukti efektif meningkatkan minat mahasiswa dalam belajar. Hal ini menjadi motivasi kami untuk melakukan hal yang sama namun dengan pendekatan yang berbeda menyesuaikan kebutuhan UNIS.

Berdasarkan hal tersebut maka Penelitian ini menghasilkan sebuah aplikasi android yang juga dapat menjadi dasar sebuah model pembelajaran berbasis multimedia edutainment dan diharapkan dapat membuktikan tingginya dampak pemanfaatan IT didalam pembelajaran mahasiswa. Dan, pertanyaan Penelitian di Penelitian ini adalah "Bagaimana membangun system informasi dalam bentuk e-learning pada pembelajaran Hukum Tajweed?

\section{Teori dan Metode \\ Teori yang digunakan}

\section{Pembelajaran Online}

Popularitas online learning disebabkan karena beberapa hal antara lain: (1) Mahasiswa dapat mengikuti pembelajaran tanpa harus datang ke kampus penyelenggara atau meninggalkan tempat bekerja atau tempat tinggal, (2) Mahasiswa dapat memilih waktu sesuai dengan waktu yang tersedia, (3) Mahasiswa 
dapat mengikuti proses pembelajaran sesuai dengan kecepatan belajar atau gaya belajar yang dimilikinya, (4) Mahasiswa dapat mengikuti pembelajaran daring dari perpengajaran tinggi tanpa dibatasi jarak geografis, (5) Mahasiswa dapat memilih mata kuliah yang dibutuhkan atau disukai, dan (6) Biaya pembelajaran daring relatif lebih murah dari pembelajaran konvensional (Murad, D. F., Heryadi, Y., Isa, S. M., \& Budiharto, W, 2020).

Menurut Arif S. Sadiman, Media pembelajaran merupakan media standar untuk menyampaikan pesan dari kedua pihak dalam pembelajaran yaitu pengajar dan pembelajar (Sadiman, 2009).

Teknologi informasi sebagai media pendukung dalam proses pembelajaran berbasis multimedia memiliki keunikan tersendiri yang dapat mempermudah proses pembelajaran berdasarkan karakteristik pembelajar (Munadi, 2010). Karena pada dasarnya media pembelajaran bagi masing-masing peserta pembelajaran dapat menyesuaikan karakteristiknya (Murad, D. F., Heryadi, Y., Isa, S. M., \& Budiharto, W, 2020). Dengan menggunakan komputer dapat mengembangkan media pembelajaran yang menarik seperti multimedia presentasi, pembuatan video dan audio pembelajaran (Tirziu, A. M., \& Vrabie, C. (2015).

Beberapa bentuk penggunaan multimedia berbasis komputer yang dapat digunakan dalam proses pembelajaran meliputi :

1. Multimedia presentasi (Mayer, R. E, 2017).

2. Pembelajaran Berbasis Komputer (CD Multimedia Interaktif)

3. Video Pembelajaran

4. E - Learning (Stanisavljevic, Z., Nikolic, B., Tartalja, I., \& Milutinovic, V, 2015).

\section{Tajwid}

Ilmu tajwid adalah (fardhu kifayah), dengan kata lain sebagian umat Islam harus mengetahuinya, namun menerapkannya (fardhu 'ain) berarti wajib bagi semua muslim. Definisi tajwid secara bahasanya adalah perbaikan, namun definisi yang diterapkan adalah melafalkan setiap huruf Al-Quran dari artikulasinya dan memberikan keistimewaan, sebagai cara pengawet lidah agar tidak salah membaca Al-Quran, juga demikian. salah satu syukur terbesar ilmu karena itu relatif dengan firman Allah (Akkila, A. N., \& AbuNaser, S. S, 2018) (Akkila, A. E. D. N., \& Naser, S. A, 2018).

Saat ini, dengan revolusi pemanfaatan komputer, banyak peneliti mengarahkan perhatiannya pada kerja program komputer untuk melayani Alquran khususnya pengajaran Tajwid, namun program-program tersebut masih sangat terbatas, dan tidak ada Batasan tertentu dari peserta didik, salah satunya hanyalah terkait cara membaca, melihat, mendengarkan dan mencari saja Elhadj, Y. O. M. (2010).

\section{Metode Penelitian}

Penelitian ini menggunakan metode kuantitatif menggunakan kuisioner sebagai media verifikasi terkait kebutuhan pembelajar. dalam mendevelop sistem nya Penelitian ini menggunakan metode aplikatif yang mengadopsi metode pengembangan system informasi scrum berbasis android (Karuppasamy, et.al., 2018). Scrum yang digunakan diantaranya adalah scrum event dan scrum artefak.

\section{Kerangka Pemikiran}

Berikut ini merupakan kerangka berfikir dalam penelitian ini :

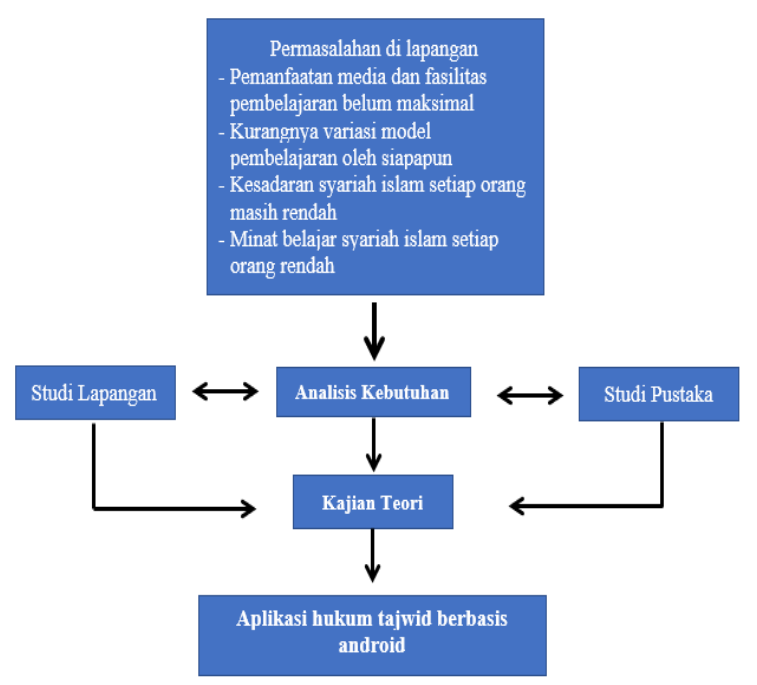

Gambar 2. Kerangka Pemikiran

\section{Hasil dan Pembahasan}

Pengambilan sampel dilakukan di Universitas Islam Syekh Yusuf Kota Tangerang, dengan fokus kepada mahasiswa, Penentuan jumlah sampel menggunakan probability sampling di mana semua elemen populasi mempunyai peluang yang sama untuk dijadikan sebagai sampel.

Penentuan jumlah responden di penelitian ini menggunakan Rumus Slovin dengan perhitungan sebagai berikut:

$\mathrm{n}=\mathrm{N} /[1+\mathrm{Ne} 2]$

di mana $\mathrm{N}=$ jumlah populasi $=312$

$\mathrm{e}=$ margin of error $=10 \%=0,01$

sehingga jumlah responden sebagai sampel dalam Penelitian ini adalah sejumlah:

$\mathrm{n}=312 /[1+312(0,01) 2]=75,728$ dibulatkan menjadi 76. 
Jurnal Pendidikan dan Aplikasi Industri (UNISTEK)

Vol. 8 No.1 Februari 2021

p- ISSN : 0126 - 4036

e- ISSN : 2716 - 0416

Kegiatan di dalam Scrum yang digunakan pada Penelitian ini adalah:

a) Perencanaan Sprint

b) Scrum Harian

c) Sprint Review

d) Sprint Retrospective

Dengan artefak scrum sebagai berikut
a) Product Backlog
b) Sprint Backlog
c) Increment

Berdasarkan tahapan-tahapan Penelitian maka dihasilkan aplikasi pintar dengan tampilan sebagai berikut:

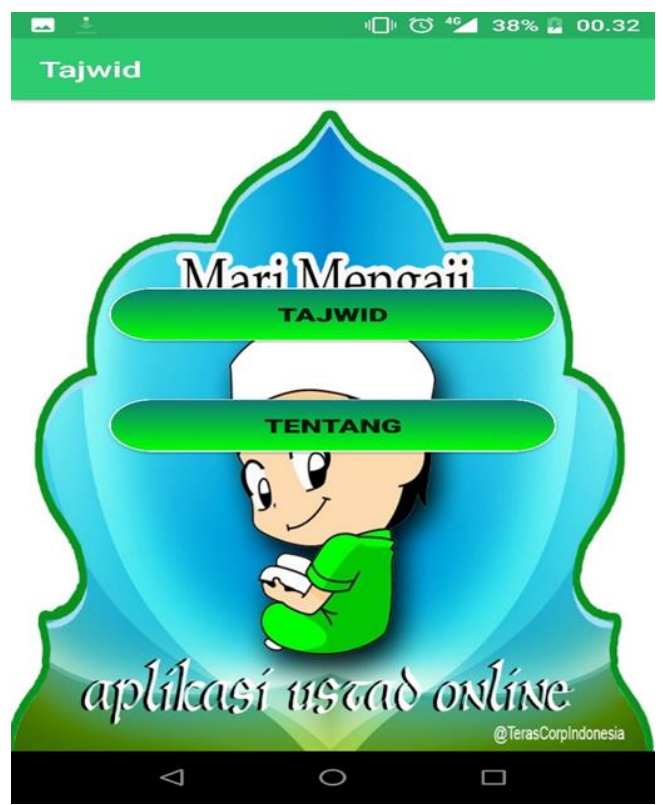

Gambar 3. Tampilan awal aplikasi

Pada tampilan awal aplikasi terdapat dua menu Tajwid dan menu Tentang, dalam menu Tajwid terdapat menu-menu hukum tajwid seperti Mad, Idgham, Izhar, Ikhfa, dll, sedangkan pada menu Tentang berisikan sejarah Tajwid, pengertian Tajwid, mim mati, nun mati, dll.

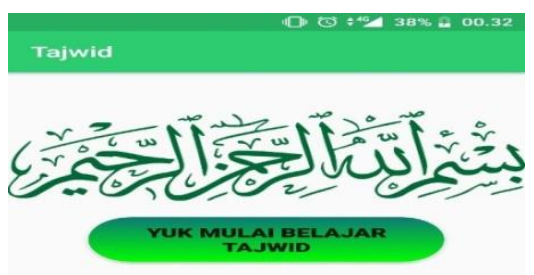

Gambar 4. Tampilan memulai belajar tajwid
Pada tampilan memulai belajar tajwid menampilan cara belajar hukum tajwid, seperti namanama hukum tajwid, pengertian dari masing-masing hukum tajwid, huruf hijaiyah yang terdapat pada masing-masing hukum tajwid, beserta contohnya.
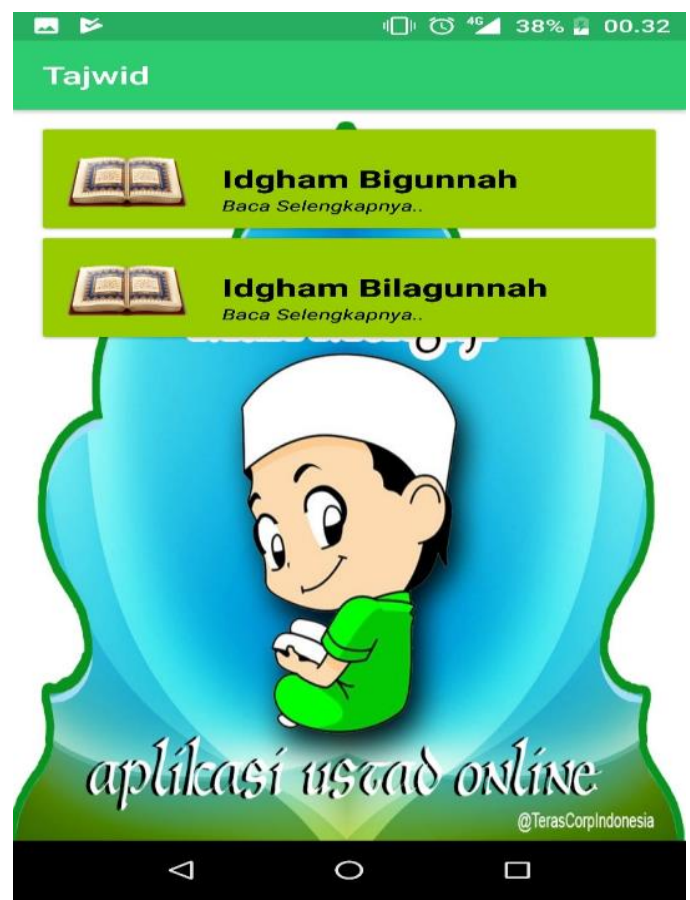

Gambar 5. Tampilan informasi idgham

Pada tampilan informasi idgham, ini salah satu contoh tampilan hukum tajwid, yaitu menjelaskan tentang idgham, macam-macam idgham serta bagaimana cara membaca dengan contohnya. 

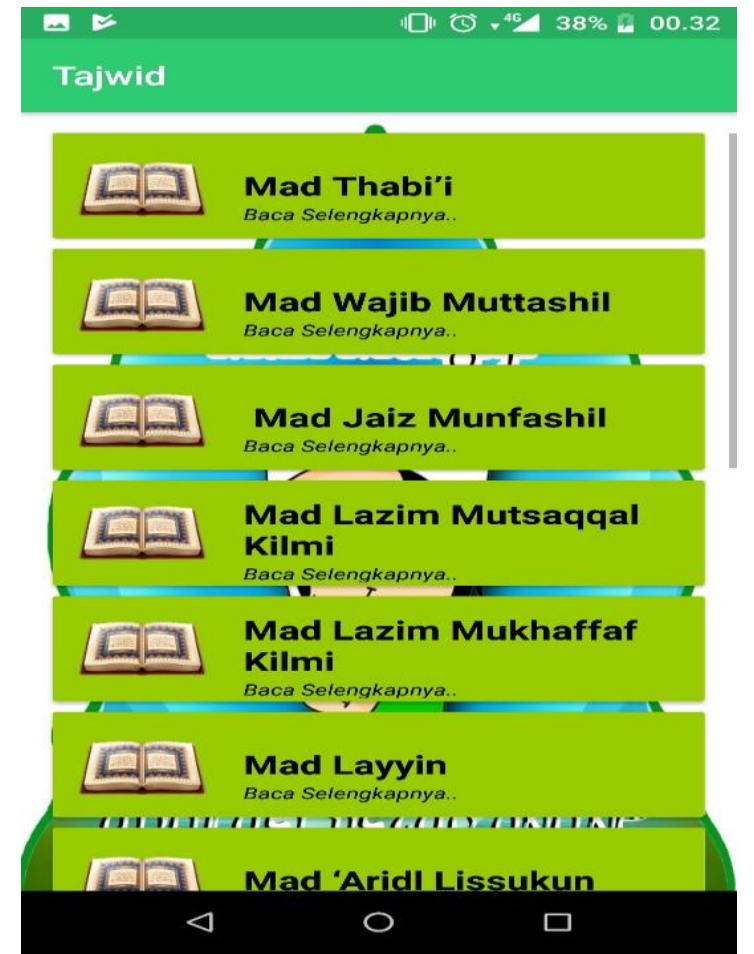

Gambar 6. Tampilan informasi ketentuan-ketentuan tajwid

Pada tampilan informasi Mad menjelaskan tentang macam-macam hukum tajwid Mad, menjelaskan perbedaan dari masing-masing mad, beserta contohnya.

Aplikasi ini sudah dicobakan ke beberapa user, peneliti melakukan testing dengan user yang sekaligus menjadi responden di Penelitian ini. Penggunaan tajwid ternyata sangat membantu user dalam memahami $\mathrm{Al}$ Qur'an dengan lebih baik dan membantu mereka dalam membaca ayat-ayat suci sesuai ketentuan membaca kitab suci yang benar. Dalam hal ini, user juga menyatakan bahwa mereka menjadi lebih yakin dalam membaca Al Quran dan tidak khawatir dengan kesalahan dalam membaca yang juga berdampak terhadap perubahan makna.

Namun untuk lebih memaksimalkan hasil Penelitian ini, maka aplikasi ini dicobakan pada salah satu kelas. Dikarenakan hasil akhir nilai di kelas tersebut belum ada (masih berproses di semester berjalan) namun kami menggunakan beberapa nilai lainnya seperti nilai kuis dan tugas. Dengan perbandingan yang sama dikathui hasilnya cukup baik dengan peningkatan $70 \%$ dari semester sebelumnya.

Meskipun hasilnya belum maksimal namun penulis yakin di akhir semester hasilnya akan lebih maksimal.

\section{Kesimpulan}

Berdasarkan hasil akhir penelitian dan uji terhadap aplikasi maka didapatkan kesimpulan sebagai berikut: a) Aplikasi hokum tajwid berbasis android lebih mudah dipahami baik oleh mahasiswa maupun dosen

b) Aplikasi ini sangat membantu dalam mempermudah dan mempercepat proses transfer knowledge pada pembelajaran

c) Aplikasi ini merangsang minat mahasiswa untuk lebih memahami hokum tajwid

\section{Daftar Pustaka}

Andersson, A., Grönlund, A. (2009). A conceptual framework for E-learning in developing countries: A critical review of research challenges. The Electronic Journal on Information Systems in Developing Countries, $38(2)$, pp. $1-16$

Akkila, A. E. D. N., \& Naser, S. A. (2018). ITS-Tutor for Teaching Rules of Tajweed the Holy Quran. Al-Azhar University, Gaza, Palestine.

Akkila, A. N., \& Abu-Naser, S. S. (2018). Rules of Tajweed the Holy Quran Intelligent Tutoring System.

Arikunto, S. Prosedur Penelitian, 2019

Elhadj, Y. O. M. (2010). E-Halagat: An e-learning system for teaching the holy Quran. Turkish Online Journal of Educational TechnologyTOJET, 9(1), 54-61.

Karuppasamy, S., Singaravel, G., \& Kaveen, P. (2018). Scrum Investigation Analysis for Android Application. Bonfring International Journal of Networking Technologies and Applications, 5(1), 12-16.

Mayer, R. E. (2017). Using multimedia for e-learning. Journal of Computer Assisted Learning, 33(5), 403-423.

McMahon, Walter W. and Geske, Terry G. (1982). Financing Education: Overcoming Inefficency and Inquety. USA: University of Illionis.

Munadi Yudhi. (2010). Media Pembelajaran (Sebuah Pendekatan Baru), Gaung Persada, Jakarta.

Murad, D. F., Hassan, R., Heryadi, Y., \& Wijanarko, B. D. (2020, October). The Impact of the COVID-19 Pandemic in Indonesia (Face to face versus Online Learning). In 2020 Third International Conference on Vocational Education and Electrical Engineering (ICVEE) (pp. 1-4). IEEE.

Murad, D. F., Heryadi, Y., Isa, S. M., \& Budiharto, W. (2020) Personalization of study material based on predicted final grades using multi-criteria usercollaborative filtering recommender system.

Sadiman, Arief S. (2009). Media Pendidikan: Pengertian, Pengembangan dan Pemanfaatannya, Rajawali Pers, Jakarta.

Stanisavljevic, Z., Nikolic, B., Tartalja, I., \& Milutinovic, V. (2015). A classification of eLearning tools based on the applied multimedia. Multimedia Tools and Applications, 74(11), 3843-3880. 
Jurnal Pendidikan dan Aplikasi Industri (UNISTEK)

Vol. 8 No.1 Februari 2021

p- ISSN : 0126 - 4036

e- ISSN : 2716 - 0416

Tirziu, A. M., \& Vrabie, C. (2015). Education 2.0: Elearning methods. Procedia-Social and Behavioral Sciences, 186, 376-380. 
Jurnal Pendidikan dan Aplikasi Industri (UNISTEK)

Vol. 8 No.1 Februari 2021

p- ISSN : 0126 - 4036

e- ISSN : 2716 - 0416 